\section{Nauplius}

The JOURnAL OF The

Brazilian Crustacean Society

e-ISSN 2358-2936

www.scielo.br/nau www.crustacea.org.br

\title{
New records of intersexuality in porcelain crabs (Crustacea: Decapoda: Anomura: Porcellanidae)
}

Luciane Augusto de Azevedo Ferreira ${ }^{1}$

(iD orcid.org/0000-0003-1683-9962

1 Museu de Zoologia, Universidade de São Paulo. Avenida Nazareth, 481, Ipiranga. 04263-000 São Paulo, São Paulo, Brazil.

ZOOBANK http://zoobank.org/urn:lsid:zoobank.org:pub:3446671F-22DC-4DB287E4-983F7B85F613

\section{ABstract}

The occurrence of intersex specimens of Lissoporcellana quadrilobata (Miers, 1884), Pisidia bluteli (Risso, 1816) and Pisidia longimana (Risso, 1816) is recorded for the first time and their secondary sexual characters analyzed. Intersex specimens were collected in regions regularly affected by pollution. There is a high possibility that intersexuality in porcelain crabs is caused by environmental contamination.

\section{KEY WORDS}

Intersex, Malacostraca, pollution, anomuran crabs, sexual characters.

Decapod crustaceans are typically gonochoric, with a more or less pronounced sexual dimorphism. In porcelain crabs, the most obvious external characters of females are three pairs of uniramous pleopods located on the third, fourth and fifth abdominal somites, although the pleopod on the third somite is sometimes absent (e.g., Polyonyx Stimpson, 1858). Males occasionally have highly modified pleopods (= gonopods) located on the second abdominal somite (gonopods are absent in some species of Pachycheles Stimpson, 1858 and Polyonyx). Male gonopods are biramous, with a long protopod, a well-developed endopod and usually a quite reduced exopod. In all decapods, gonopores are situated on the coxae of the third pereopods (P3) in females, and on the coxae of the fifth pereopods (P5) in males. The specimens that have gonopore openings on both P3 and P5 are called intersex individuals (Turra, 2004).

In porcelain crabs, intersexuality has been only reported in two species: Porcellana platycheles (Pennant, 1777) and Pisidia longicornis (Linnaeus, 1767) by Ferreira and Guzmán (2013) and Ferreira (2015), respectively. Ferreira (2015) identified an ovigerous intersex specimen in P. longicornis, representing the first record of this condition in porcelain crabs.

The present paper aims to report new records of intersexuality in three additional porcellanid crabs: Lissoporcellana quadrilobata (Miers, 1884), Pisidia bluteli (Risso, 1816) and Pisidia longimana (Risso, 1816). 
The porcellanid material examined (Appendix 1) is deposited in the National Museum of Natural History, Smithsonian Institution, Washington DC, USA (USNM), and was thoroughly examined under a stereomicroscope. The sex of individuals was determined based on the position of the gonopores on either P3 (males) or P5 (females), whereas secondary sexual characters were scored based mainly on the morphology of the sternum, abdomen and pleopods. In addition, gill and abdominal chambers of the porcellanid specimens were examined for presence of macro-parasites (bopyrid isopods and rhizocephalan barnacles).

Abbreviations used include: cw, carapace width, taken at the level of its widest point, in millimeters (mm); P3, P5, pereopods 3, 5 .

Of 23 specimens of $L$. quadrilobata examined, two individuals were determined as intersex (Fig. 1A). Both intersex specimens have male dominant characters such as male gonopores on the P5 and well-developed gonopods on the second abdominal somites, in addition to well-developed female gonopores on the P3.
Sixteen specimens of $P$. bluteli were examined and five individuals among them were determined as intersex (Fig. 1B, C). Three of the intersex specimens possess male dominant characters (a pair of male gonopores and well-developed gonopods) and a pair of rudimentary female gonopores. The other two intersex specimens have female dominant characters such as broad thoracic sternum, female pleopods and well-developed female gonopores, in addition to male gonopores.

Of approximately 300 specimens of $P$. longimana examined, four intersex were identified (Fig. 1D). All the individuals have dominant male characters (a pair of male gonopores and well-developed gonopods) in addition to a pair of well-developed female gonopores.

No parasitic bopyrid isopods or rhizocephalan barnacles were found in intersex specimens examined, and no abnormalities were found on the carapace, pereopods, abdomen or pleopods.

Different hypotheses have been suggested to explain intersexuality in crustaceans, including parasitism (Nielsen, 1970; Ginsburger-Vogel, 1991),
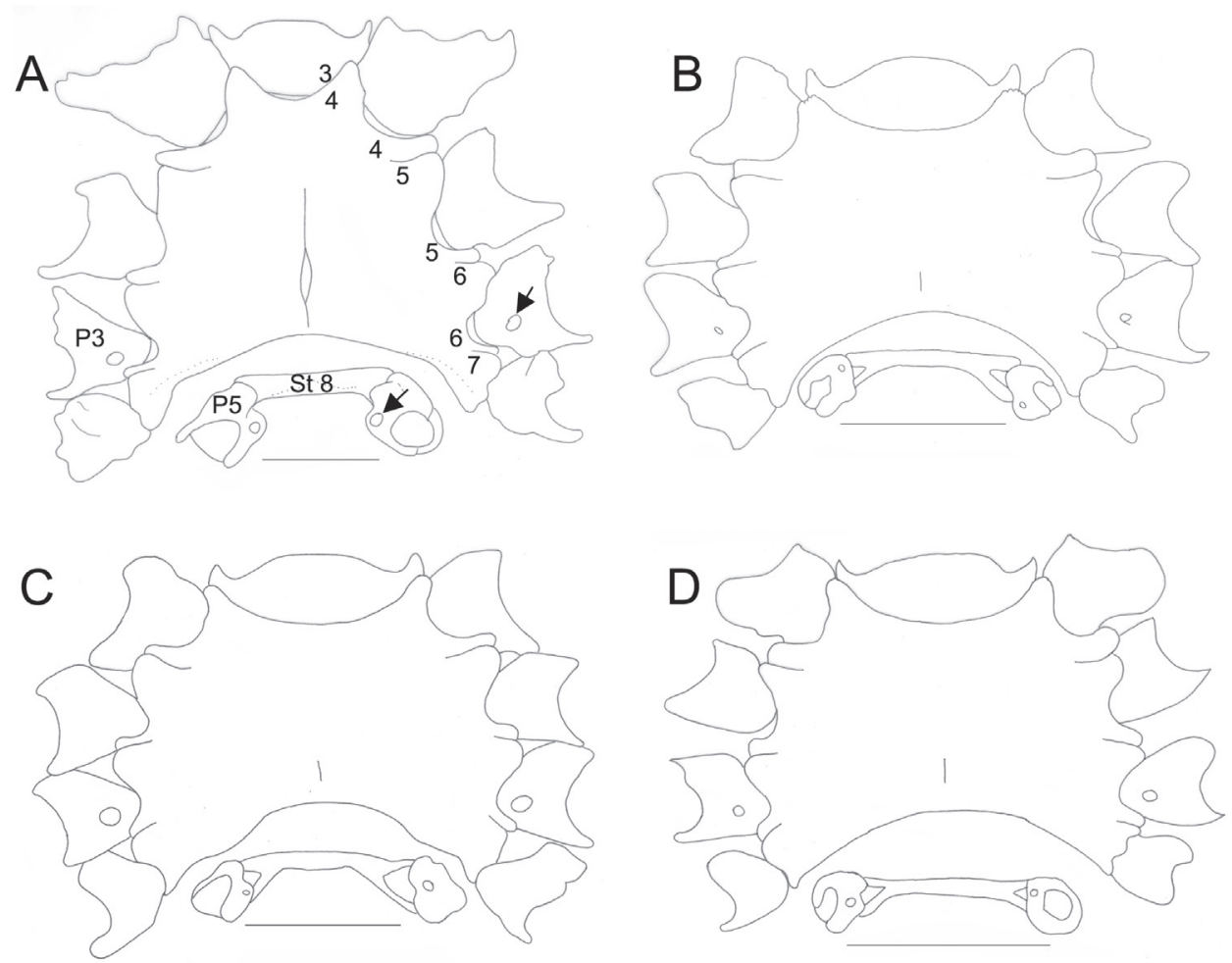

Figure 1. P1-P5 coxae and thoracic sternum of intersex specimens, ventral view. A. Lissoporcellana quadrilobata (Miers, 1884), male dominant characters, cw 8.0 mm (USNM 229590). B. Pisidia bluteli (Risso, 1816), male dominant characters, cw $3.9 \mathrm{~mm}$ (USNM 1277824). C. Pisidia bluteli (Risso, 1816), female dominant characters, cw $4.1 \mathrm{~mm}$ (USNM 1277824). D. Pisidia longimana (Risso, 1816), male dominant characters, cw $2.9 \mathrm{~mm}$ (USNM 152181). Abbreviations: St8, thoracic sternites 8; 3/4-6/7, thoracic sternal sutures. Arrows: female (P3) and male (P5) gonopores. Scale bars $=1 \mathrm{~mm}$. 
genetic abnormalities (Hough et al., 1992; Ferreira and Guzmán, 2013), environmental contamination (Olmstead and LeBlanc, 2007; Mazurová et al., 2010; Ford, 2012) and social organization (Tóth and Bauer, 2008).

The occurrence of intersex specimens is frequently attributed to localities suffering from pollution (Gusev and Zabotin, 2007; Yang et al., 2008; Fantucci et al., 2009; Sant'Anna et al., 2010; Ferreira and Guzmán, 2013; Ferreira, 2015). In the present study, intersex individuals of L. quadrilobata, P. bluteli and P. longimana were indeed collected from regions regularly affected by pollution resulting from activities of coastal industries, harbors, ligthhouses and boating. Localities within the sampling region often experience impacts from discharge of commercial vessels, fuel and other discharge of pollutants (Aissaoui and Hassine, 2012; Perkovic et al., 2016; Randone, 2016). Ferreira (2015) have already observed intersex individuals of Pisidia longicornis collected from a polluted region caused by sunken oil tankers or by illegal fuel discharges. Therefore, it is possible that intersexuality observed in porcelain crabs in the studied area is caused by environmental contamination.

Since no bopyrid or rhizocephalan parasites were found associated with intersex specimens, and no abnormalities were found on their carapace, abdomen or pleopods, it is unlikely that parasitism is the cause of intersexuality in these crabs. Due to the fact that the incidence of porcellanid intersex specimens is low, another reasonable hypothesis is that intersexuality can be attributed to a genetic abnormality.

\section{ACKNOWLEDGEMENTS}

I gratefully thank Marcos Tavares (MZUSP) for providing working space, and Rafael Lemaitre (USNM) for granting access to the collection under his responsibility. Thanks also extend to Karen Reed (USNM) for her kind assistance throughout the execution of this work. This work was supported by Conselho Nacional de Desenvolvimento Científico e Tecnológico, CNPq under grant 165957/2015-8.

\section{References}

Aissaoui, A. and Hassine, O.K.B. 2012. Occurrence of harmful dinoflagellates in the Punic Harbors of Carthage (Gulf of Tunis, Tunisia) and their correlations with the physicochemical parameters. Bulletin de l'Institut National des Sciences et Technologie de la Mer de Salammbô, 39: 127-140.

Fantucci, M.Z.; Biagi R. and Mantelatto, F.L. 2009. Use of pleopod morphology to determine sexual dimorphism and maturity in hermit crabs: Isocheles sawayai as a model. Helgoland Marine Research, 63: 169-175.

Ferreira, L.A.A. 2015. Intersexuality in the porcellanid crab Pisidia longicornis (Crustacea: Decapoda: Anomura: Porcellanidae). Zoologia, 32: 176-178.

Ferreira, L.A.A. and Guzmán, G. 2013. Primer registro de intersexualidad en Porcellana platycheles (Pennant, 1777) (Decapoda: Anomura: Porcellanidae). Latin American Journal of Aquatic Research, 41: 606-610.

Ford, A.T. 2012. Intersexuality in Crustacea: an environmental issue? Aquatic Toxicology, 108: 125-129.

Ginsburger-Vogel, T. 1991. Intersexuality in Orchestia mediterranea Costa, 1853, and Orchestia aestuarensis Wildish, 1987 (Amphipoda): a consequence of hybridization or parasitic infestation? Journal of Crustacean Biology, 11: 530-539.

Gusev, O. and Zabotin, Y. 2007. Observation of intersexuality in land hermit crabs (Anomura: Coenobitidae). Journal of the Marine Biological Association of the United Kingdom, 87: 533-536.

Hough, A.R.; Bannister N.J. and Naylor, E. 1992. Intersex in the mysid Neomysis integer. Journal of Zoology, 226: 585-588.

Mazurová, E.; Hilscherová, K.; Šídlová-Štěpánková, T.; Köhler, H.R.; Triebskorn, R.; Jungmann, D.; Giesy, J.P. and Bláha, L. 2010. Chronic toxicity of contaminated sediments on reproduction and histopathology of the crustacean Gammarus fossarum and relationship with the chemical contamination and in vitro effects. Journal of Soils and Sediments, 10:423-433.

Nielsen, S.O. 1970. The effects of the rhizocephalan parasites Peltogaster paguri Rathke and Gemmosaccus sulcatus (Lilljeborg) on five species of paguridan hosts (Crustacea, Decapoda). Sarsia, 42: 17-32.

Olmstead, A.W. and LeBlanc, G.A. 2007. The environmentalendocrine basis of gynandromorphism (intersex) in a crustacean. International Journal of Biological Science, 3: 77-84.

Perkovic, M.; Hribar, U. and Harsch, R. 2016. Oil Pollution in Slovenian Waters: The Threat to the Slovene Coast, Possible Negative Influences of Shipping on an Environment and Its Cultural Heritage. The Handbook of Environmental Chemistry, 1: $1-25$.

Randone, M. 2016. MedTrends Project: Blue Growth Trends in the Adriatic Sea - the challenge of environmental protection. WWF Mediterranean Press, 79p.

Sant'Anna, B.S.; Turra, A. and Zara, F.J. 2010. Simultaneous activity of male and female gonads in intersex hermit crabs. Aquatic Biology, 10: 201-209.

Tóth, E and Bauer, R.T. 2008. Synalpheus paraneptunus (Crustacea: Decapoda: Caridea) populations with intersex gonopores: a sexual enigma among sponge-dwelling snapping shrimps. Invertebrate Reproduction \& Development, 51: 49-59.

Turra, A. 2004. Intersexuality in hermit crabs: reproductive role and fate of gonopores in intersex individuals. Journal of the Marine Biological Association of the United Kingdom, 84: 757-759.

Yang, G; Kille, P. and Ford, A.T. 2008. Infertility in marine crustacean: Have we been ignoring pollution impacts on male invertebrates? Aquatic Toxicology, 88: 81-87. 
Appendix 1. Porcellanid intersex examined in the present study. Collection numbers are indicated in brackets.

Lissoporcellana quadrilobata (Miers, 1884). Philippines, Sulu Archipelago, Jolo, 5.5 miles northwest of Jolo Light, $06^{\circ} 09^{\prime} \mathrm{N} 120^{\circ} 58^{\prime} \mathrm{E}, \mathrm{R} / \mathrm{V}$ “Albatross”, St. 5141, 53 m, 12.ii.1908, 2 intersexes, cw 8.0, 4.6 mm (USNM 229590). Pisidia bluteli (Risso, 1816). Croatia, Cervar, near Porec, in Mytilus beds, 5 intersexes, cw 3.9, 4.1, 4.3, 4.5, 5.2 mm (USNM 1277824).

Pisidia longimana (Risso, 1816). Italy, Golfo di Manfredonia, 41 $25^{\prime} 18^{\prime \prime} \mathrm{N} 16^{\circ} 13^{\prime} 30^{\prime \prime} \mathrm{E}, 15 \mathrm{~m}$, C. Froglia et al. coll., 06.vii.1974, 1 intersex, cw 2.9 mm (USNM 152181). Tunis, Salammbo, grass flats adjacent to northern Punic Port, St. 207B, algae wash, M.L. Jones coll., 19.viii.1973, 1 intersex, cw 2.7 mm (USNM 1278020); St.211B, R.B. Manning coll., 1 intersex, cw 3.4 mm (USNM 1278015); St. 211C, R.B. Manning coll., 21.viii.1973, 1 intersex, cw $3.9 \mathrm{~mm}$ (USNM 1278021). 